УДК [338.22:316.334.3](477)

DOI: $10.18524 / 2413-9998 / 2019.2(42) .177074$

\author{
N. V. Orlova, \\ $\mathrm{PhD}$ in Economics, Associate Professor \\ of Management and Innovation Department, \\ of Odessa I. I. Mechnikov National University \\ 24/26 Frantsuzskyi Boulevard, 65058, Odessa, Ukraine, \\ e-mail: lemorl@rambler.ru
}

\title{
THEORETICAL RESEARCHES AND PROBLEMS OF REALIZATION OF SOCIAL RESPONSIBILITY OF BUSINESS
}

The purpose of this article is to analyze the conceptual foundations of social responsibility of business and the problems of implementation of socially responsible practices in Ukraine. The approach is to present the importance of this activity, a review of the evolution of the corporate social responsibility concept, the main directions and difficulties of the implementation of these activities in practice.

For this study we used the integrated CRS group theories, including Instrumental theories, Political theories, Integrative theories, Ethical theories. Within this classification the more detailed, already existing, directions of research are considered.

All basic CSR models include three levels: 1. compliance with legislation, 2. social responsibility for profit 3 . social activity that is not directly related to the receipt of benefits.

The article also discusses a number of key modern areas of research of Political CSR, the business case for CSR, upstream/ downstream CSR, CSR in emerging economies, Corporate Social Irresponsibility (CSiR). An important area of research today is the relationship between the concepts of CSR and strategic management. In this case, social responsibility is considered as a paradigm "principles — processes — results". This approach involves identifying specific ways to integrate CSR into corporate strategy.

Based on the research materials of Ukrainian scientists, the main directions, forms and problems of implementation of socially responsible practices in Ukraine are analyzed.

Key words: corporate social responsibility (CSR); corporate reputation; socially responsible practices; stakeholders; business environment.

The globalization of economic life, which has significantly increased in recent decades, has led companies to operate in international interdependent markets with a set of changing rules. Therefore, a universally recognized goal for economic actors is the pursuit of "sustainable development", which 
is understood as harmonious and balanced development, which implies that all institutional changes, investment and scientific and technical projects, the exploitation of natural resources should be aimed at expanding the economic and social potential of society. Of course, the meaning of the company is the creation of wealth and profit, but while operating, the company needs a social space and a developed consumer. The social role of the company is a necessary component of modern production systems. Therefore, the concept of "sustainable development" at the company level actually coincides with the implementation of the principles of corporate social responsibility.

In industrialized countries, social responsibility has long been seen as an element of strategic management and an important area of corporate activity. In countries in transition and developing economies, where the tradition of social responsibility of business is just emerging, CSR is interpreted more narrowly, in practice, mainly to charity and sponsorship. Although today, in the difficult economic, political and demographic conditions of development of Ukraine, it is the social responsibility of business, according to some Ukrainian researchers, could become an unifying national idea [1, p. 5].

The problems of social responsibility of business have been discussed for decades both in the theoretical aspect and from the perspective of specific forms of implementation. The study of this issue was initially conducted by the representatives of the Western economic school. The most famous were the works of such scientists as Ackerman R. W., Aupperle K. E., Barnett M. L., Bowen H. R., Bundy J., Davis K., Dahlsrud A., Donaldson T., Carroll A. B., Frederick W., Fombrum. C. J., Levitt T., Freeman R. E., Friedman M., Moon J., Palazzo C., Scherer A. G., Schwartz M. S., Waddock S. A., Wood D. J., Zadek S., Zhao X. For domestic economic science, this issue has become relevant in parallel with the processes of market transformation. A major contribution to the study of various aspects of social responsibility of business has been made by A. Crow, Halchak H., O. grishnova, A. Zaretsky, A. Zinchenko, A. Kolot, A. Koshi, letenka S., Misko A., Savchenko I., T. Chernata

The first in-depth scientific monograph dealing specifically with this issue, was the work of H. Bowen, "Social Responsibilities of the Businessman" (1953). It was an attempt to institutionalize the social responsibility of business. According to the author, the latter meant "the obligations of businessmen to pursue those policies, to make those decisions, or to follow those lines of action that are desirable in terms of the objectives and values of our society" [2, p. 11]. The provisions of this work have been perceived differently by the scientific community. 
The greatest attention in the analysis of the contribution to the theory of social responsibility of business among the supporters of Bowen is usually paid to the works of A. Carroll, who suggested its multilevel nature, including economic, legal, ethical and philanthropic forms that meet the requirements of society to the economic entity. For a definition of social responsibility to fully address the entire range of obligations business has to society, it must embody the economic, legal, ethical, and discretionary categories of business [3, p. 499].

Economic responsibility involves the implementation of the production process and the enterprise profit. The legal part consists in strict compliance with the laws. These two levels are basic and mandatory for the firm. Ethical responsibility is not specified and is not regulated by law, but it meets the expectations of the company and involves a counter-reaction of the enterprise. The last, fourth level - the discretionary responsibility - is a voluntary participation of the enterprise in the life of society [3, p. 500].

The pyramid proposed by A. Carroll makes it possible to streamline the structure of business responsibility, to present it in the form of a certain system consisting of interconnected links. However, this in-depth theoretical study does not contain specific recommendations, and the terms "requirements" and "expectations" of society do not have strict certainty and evaluation measures.

Along with the approval of social responsibility of business, there were also critical assessments of this approach.

A different view was expressed by Theodore Levitt. In his Harvard Business Review article, "The dangers of social responsibility", he warned that "government's job is not business, and business's job is not government", "the social responsibility of business is to generate profit". Levitt thought that business's job was to "take care of the more material aspects of welfare". He feared that attention to social responses would detract from the profit motive that was so essential for business success [4, p. 48, 49].

Likewise, Friedman in a New York Times article "The Social Responsibility of Business is to Increase its Profits" approved "There is one and only one social responsibility of business - to use its resources and engage in activities designed to increase its profits so long as it stays within the rules of the game". He notes that "In a free-enterprise, private-property system, a corporate executive is an employee of the owners of the business. He has direct responsibility to his employees. That responsibility is to conduct the business in accordance with their desires, which generally will be to make as much money as possible while conforming to their basic rules of the society, 
both those embodied in law and those embedded in ethical custom" [5]. The scientist is critical of the activities of managers who share the principles of social responsibility and thus invade the sphere that is beyond their professional competence.

This point of view, voiced by Milton Friedman, can be called the theory of corporate egoism: there is only one social responsibility of business - to use its resources to increase profits in compliance with existing legislation. This target setting is to business success and maximization of profit as the only parameter of development of the company, has led to the emergence of theories justifying the reconciliation of the non-compliance with moral principles in the name of material gain. According to them, any actions in business are morally justified if they do not contradict the law (the principles of morality and justice are not taken into account when making decisions).

The point of view, called the theory of corporate altruism, is directly opposite to the theory of M. Friedman and appeared in parallel with his publications. Its main idea is that business should care not only about the growth of profits, but also ensure the maximum possible contribution to the solution of social problems. The authorship of this theory belonged to the Committee on Economic Development. According to its recommendations, firms can not withdraw from social problems, corporations are obliged to make a significant contribution to improve the quality of American life.

The theory of intelligent egoism expresses the centrist approach. It means that the social responsibility of a business is simply a "good business" as it reduces long-term profit losses. A corporation reduces its current profits by spending money on social and philanthropic programs but in the long term it creates a favorable social environment and sustainable profitability. In other words, the necessity of social investments and programs as a guarantee of stability and security of the company is recognized. The limitation of this approach is that such a concept does not involve the introduction of a social component in the strategy and philosophy of doing business [6, p. 28].

The abundance of points of view on the role of business in the process of strengthening the social foundations of society, the emergence of various definitions of the concept of corporate social responsibility (such as corporate social activities, corporate social susceptibility, stakeholder theory, the theory of corporate citizenship) made this problem so "hackneyed" that notwithstanding all its importance one involuntarily starts agreeing with the opinion of C. Network who noted that "The phase corporate social responsibility has been used in so many different contexts that it has lost all meaning" $[7$, p. 58]. 
From our point of view, this situation arose due to the fact that the very concept of social responsibility is the subject of research of a number of Sciences (Philosophy, Economics, Sociology, Political Science, Psychology, Business Ethics). The attempts to analyze its individual sides from the perspective of the specifics of a particular area of knowledge and the lack of comprehensive research lead to limited results.

Today, the most complete systematization of approaches to corporate social responsibility is contained in the work of D. Mele and E. Garrigue "Corporate Social Responsibility Theories: Mapping the Territory" [8]. The authors identify four areas of CSR research that allow us to group existing theories conditionally.

1. Instrumental theories based on the consideration of the company solely as a tool for the creation of wealth, and social activities - as a means to achieve economic results. This group of theories includes some subgroups:

1.1. Maximizing the shareholder value as the highest criteria for evaluating corporate social activity.

1.2. Strategies for achieving competitive advantages implemented in the long-term period. The following three approaches are typical for this direction:

- Social investments in a competitive context. Proponents of this approach argue that investing in charities can be useful for creating conditions for a firm's competitive advantage by creating more social value than individual donors or the government can create (for example, educational programs conducted for students at the expense of the company's own funds).

Natural resource-based view of the firm and dynamic capabilities. This approach is based on the company's ability to achieve better results than its competitors through the interaction of human, organizational and material resources over the long term, as well as the organizational and strategic procedures through which managers acquire these resources, modify, integrate and combine them to create new value strategies.

- Strategies for the bottom of the economic pyramid, in which the authors see more opportunities for innovation rather than problems. One way to solve this problem is "disruptive innovation": products or services that change the value of the market. These products have other features or conditions that are used by customers in traditional markets and therefore can only be introduced for new customers or using less complex applications for specific customer groups. At the same time, old products become uncompetitive simply because the parameters on the basis of which the competition took place earlier become insignificant. The aim of these strategies is to 
"turn the poor into active consumers" by producing low-cost products and taking into account the special needs of the population. As an example of the implementation of this mechanism, the development of a simpler product (for example, a phone with fewer options) for elderly people at an affordable price in order to achieve a competitive advantage in the market;

1.3. Cause-related marketing. Theories related to marketing strategy and development of "virtuous", socially significant marketing, the main task of which is to increase sales and revenues of the company by giving the company the image of a socially responsible, honest organization.

2. Political theories, which explore the power of business in society and the degree of responsibility in the approach to the implementation of this force in the political arena. Garriga E. and Mele D. distinguish among the most important of this group of theories:

2.1. Corporate constitutionalism, based on the idea that a company is a social institution and should exercise power responsibly. The most prominent representative of this direction is K. Davis. He formulated two principles according to which business should manage its influence on the population: "the social power equation" ("social responsibilities of businessmen arise from the amount of social power that they have") [9, p. 48] and "the iron law of responsibility" ("In the long run those who do not use power in a manner which society consumers responsible will tend to lose it") [10, p. 73].

2.2. Corporate citizenship. It is a concept with three different meanings. In the form of a limited vision, it includes corporate philanthropy, social investment, or fulfilling certain responsibilities to the local community; another, broader approach, sees it as equivalent to CSR. The most ambitious vision is to address the challenge of the company to enter the citizenship scene if the government is unable to protect citizens in a global context. Despite significant differences in this group of theories, the authors highlight some common points: a strong sense of company responsibility towards local communities, associations and environmental care. As a result of corporate globalization, the care for the local community is gradually becoming a global problem.

3. Integrative theories, which substantiate the company's role in identifying, collecting social demands and responding to social needs in order to achieve social legitimacy and greater recognition and social prestige. This group of theories includes:

3.1. Issues management. This theory assumes the management of social processes that the company identifies, evaluates and reacts to, and that can have a significant impact on its functioning. 
3.2. The principle of public responsibility. Its proponents argue that the actual conduct of business depends on appropriate government policies, including a general pattern of social behaviour reflected in public opinion, formal legal requirements and their practical application.

3.3. Stakeholder management. Its advantage is the increased sensitivity of the company to the external environment, but also a deeper understanding of the interconnected agents of the dilemmas faced by organizations.

4. Ethical theories based on the ethical responsibility of business to society. They are based on the principles that express what should and should not be done to build a better society. That is, it is necessary to establish a certain "set of rules", how corporations and managers should behave, and to determine the "normative core of ethical principles". Among the main approaches Garriga E. and Mele D. distinguish the following:

4.1. Universal rights concept, which assumes that the activities of a corporation should be based on the respect for human rights and aimed at maintaining economic, social and political justice in the regions of its activities.

4.2. Sustainable development concept which aims at improving human potential. In order to assess its own sustainability, the company must adopt a "triple goal", including not only the economic aspects of the firm's activities, but also social and environmental ones. For the first time the term "Sustainable development" was officially used in the report of the World Commission on Environment and Development (United Nations) in 1987: "sustainable development" seeks to meet the needs of the present without compromising the ability to meet the future generation to meet their own needs" [11]. Although initially concerned with the environment, it was further recognized that sustainable development could not be considered outside the social context. And today sustainable development concept "requires the integration of social, environmental, and economic considerations to make balanced judgments for the long term".

Today CSR norms are included in the sustainable development programs existing under the auspices of the UN. First World Forum on sustainable development (1992) adopted a Declaration setting out the basic principles of the concept. The world summit in Johannesburg further developed a CSR commitment framework and an action plan for national governments to implement socially responsible practices. The Declaration stated "the duty of private sector representatives - large and small companies - to contribute to the development of just and sustainable communities and societies" [12].

Summarizing all existing basic models of CSR, it can be noted that they include three levels. 
The first level is compliance with the law. It is mandatory for all companies and reflects public requirements. This implies a legal obligation to comply with and fulfill the requirements provided for by the rule of law, which is realized in the legitimate behavior of subjects approved or encouraged by the state, and if violated, the offender's obligation is to undergo condemnation, restriction of material, legal or personal rights.

The second level is social responsibility, implemented for the purpose of making a profit. This level of responsibility has a very broad interpretation. This includes both responsibility for internal stakeholders (taking care of their own staff, raising the level of qualifications of employees, creating comfortable conditions for production and personal life), and also to external ones (a line of behavior to win the trust of consumers, partners, shareholders).

The third level is social activity that is not directly related to obtaining benefits. This implies the firm's acceptance of responsibility to improve the quality and standard of living of citizens of the country (charity, volunteering).

For the population, the first and third levels are the most tangible and significant, for the entrepreneur - the second. Different approaches to the characterization of social responsibility focus on one of the three levels.

In our opinion, it is the presence of various levels and forms of manifestation of social responsibility of business that create difficulties in the development of specific indicators of the degree of responsibility of the company. Attempts to impose any of the integral indicator of CSR are usually found to be unconvincing. The proposed coefficients allow us to get an idea of the investment activity of the company, its financial stability, participation in the formation of human capital. However, we should not forget that life is more complicated than theoretical schemes. The proposed estimated coefficients of social responsibility can characterize the activities of the company mainly at the micro level.

The development and complexity of forms of economic life, the processes of economic globalization, the strengthening of the political role of business led to the emergence of new methodological approaches to the analysis of corporate social responsibility. This led to the formation of concepts of political CSR (pcsr), business case for CSR, ascending/ descending CSR, CSR in developing countries, corporate social irresponsibility (CSIR).

An important area of research today is the integration of CSR concepts and strategic management, which involves the definition of specific ways to integrate CSR into corporate strategy. In this case, social responsibility is considered as a paradigm "principles - processes - results" and in practice becomes the object of management. CSR is interpreted as a factor of forma- 
tion of long-term competitive advantages of the company and increase of its corporate stability. And the main goals of CSP (corporate social performance) are defined as meeting the needs of stakeholders. This means that corporate governance cannot be reduced to management solely for the purpose of improving return on capital, ensuring the well-being of owners and protecting their interests. Strengthening mutually beneficial relationships with the stakeholder is in the long-term interests of the company.

This approach involves the creation of an organizational structure of CSP management, i.e. the functions of identifying stakeholders, identifying their requests, managing relations with them, integrating this system of relations into the company's strategy. All of the above can be described as the professionalization of CSR. And CSP itself becomes an integral component of corporate governance, both in terms of internal management system and external communications.

However, if we talk about the specific implementation of CSP in Ukraine, it should be noted that CSR has not yet become part of the strategic management of Ukrainian companies. The results of a study commissioned by the CSR Development Center in 2018 showed that although $83 \%$ of companies carry out activities that can be classified as socially responsible activities, only $52 \%$ of them have a strategy for such business behavior, and the budget formed for this purpose - in $24 \%$ of cases. A system of indicators for evaluation of results of these activities are $12 \%$ and reports of up to $13 \%$ of the companies [13, p. 25].

In most companies $(72 \%)$ proposals for socially responsible practices are put forward and monitored by the company's management. In $25 \%$ of companies CSR ideas are generated by the company's employees. Special departments of CSR are available only in $2 \%$ of companies [13, p. 27].

The main motives that encourage companies to implement socially responsible activities are moral considerations (53\%), improving the company's reputation (26\%), increasing employee loyalty $(23 \%)$. The impact on financial performance was not identified by the survey participants. Moreover, $15 \%$ of firms that do not implement socially responsible practices as the reasons for such behavior identified the lack of incentive for business development, the senselessness of spending money and time, Association with the motive of marketing cunning [13, p. 13, 14].

CSR has been in Ukraine for more than fifteen years, but the practical aspect of this activity is developing much more slowly and less consistently than the theoretical one. To a certain extent, this is due to the lack of funds from enterprises, the lack of awareness of positive examples and the results 
of these activities, the lack of educational programs on the specific forms and methods of these activities. Of course, in the context of economic instability associated with global crises and domestic political problems, it is difficult to expect from Ukrainian enterprises the same scale of social programs as from advanced foreign firms. As an impetus for the development of this activity, it would be possible to use, as in the countries of the European Union, the legislative consolidation for state and large companies of the requirements for mandatory disclosure of non-financial information in annual reports. According to "Directive 2014/95 / EU on disclosure of non-financial and diversity information", which makes adjustments to Directive 2013/34 / EU, "large undertakings which are public-interest entities exceeding on their balance sheet dates the criterion of the average number of 500 employees during the financial year shall include in the management report a non-financial statement containing information to the extent necessary for an understanding of the underlying's development, performance, position and impact of its activity, relating to, as a minimum, environmental, social and employee matters, respect for human rights, anti-corruption and robbery matters". The term "enterprises of interest to the public" is defined in article 2 of Directive 2014/95 / EU and includes listed companies in the EU markets, as well as credit institutions, insurance companies and other enterprises that are defined by the EU member States on the basis of their activities, size or number of employees [14].

A significant incentive for the implementation of socially responsible practices could be the introduction of preferential taxation. Naturally, such a step can have contradictory macroeconomic consequences. However, it could be extended to investments made by companies in those areas that are recognized at the regional and national level as priority social tasks (for example, investments in medical programs for the improvement of the population, in programs for improving the energy efficiency of production).

The implementation of such measures requires the existence of a Single national program of social responsibility, which would be spelled out the main stages, institutional mechanisms and forms of CSR.

Business is involved not only in the economic, but also in the social life of society, so its responsibility should be comprehensive. The formation of a system of interaction between the state and the business sector to ensure the solution of socio-economic problems should be in the field of view of specialists in the field of state and corporate governance, legislative and Executive leadership of the country and regions. 


\section{Bibliography}

1. Грішнова О. А., Міщук Г. Ю., Олійник О. О. Соціальна відповідальність у трудових відносинах: теорія, практика, регулювання ризиків: Монографія. Рівне : НУВГП, 2014. 216 c.

2. Bowen, H. R. Social Responsibilities of the Businessman. New York : Harper and Row, 1953, $267 \mathrm{p}$.

3. Carroll, A. B. A Three-Dimensional Conceptual Model of Social Performance, The Academy of Management Review, 1979, Vol. 4, № 4, pp. 497-505.

4. Levitt, T. The Dangers of Social Responsibility, Harvard Business Review, 1958, Vol. 36, № 5, pp. 41-50.

5. Friedman, M. The Social Responsibility of Business is to Increase its Profits, The New York Times Magazine, September 13, 1970. URL: http://www.academia. edu/3267140/The_social_responsibility_of_business_is_to_increase_its_profits

6. Kurenko, R. N. KSO: poisk. KSO svoimi rukami, 2009, № 1, pp. 28-29. URL: http://www.csrjournal.com.

7. Sethi, S. P. Dimesions of Corporate Social Perfomance: An Analytical Framework, California Management Review, 1975, Vol. 17, № 3, pp. 58-64.

8. Garriga E., Mele D. Corporate Social Responsibility Theories: Mapping the Territory, Journal of Business Ethics, 2004, No 53. URL: http://www.environmentalmanager. org/wp-content/uploads/2008/04/csr-theories.pdf

9. Davis, K. Understanding The Social Responsibility Puzzle: Business Horizons, 1967, 10 (4), pp. 45-51.

10. Davis, K. Can Business Afford to Ignore Corporate Social Responsibilities? California Management Review, 1960, 2, pp. 70-76.

11. World Commission on Environment and Development: 1987, Our Common Future (Oxford University Press, Oxford). URL: https://sswm.info/sites/default/files/ reference_attachments/UN\%20WCED\%201987\%20Brundtland\%20Report.pdf

12. Heinrich Boell Foundation's Web Site on the World Summit for Sustainable Development, Johannesburg. (2002). URL: www.worldsummit2002.org.

13. Зінченко А., Саприкіна М. Розвиток КСВ в Україні: 2010-2018. Київ : Видавництво «Юстон», 2017, 52 с.

14. 14. Directive 2014/95/EU of the European Parliament and of the Council of 22 October 2014 (amending Directive 2013/34/EU as regards disclosure of nonfinancial and diversity information by certain large undertakings and groups). (2014) URL: https://eur-lex.europa.eu/legal content/EN/TXT/PDF/?uri=CELEX:3 2014L0095\&from $=\mathrm{EN}$

\section{Н. В. Орлова,}

кандидат экономических наук, доцент, доцент кафедры менеджмента и инноваций Одесский национальный университет имени И. И. Мечникова Французский бульвар, 24/26, 65058, г. Одесса, Украина e-mail: lemorl@rambler.ru 


\title{
ТЕОРЕТИЧЕСКИЕ ИССЛЕДОВАНИЯ И ПРОБЛЕМЫ РЕАЛИЗАЦИИ СОЦИАЛЬНОЙ ОТВЕТСТВЕННОСТИ БИЗНЕСА
}

Целью статьи является анализ концептуальных основ социальной ответственности бизнеса и проблем реализации социально ответственных практик в Украине. В работе представлен обзор эволюции понятия корпоративной социальной ответственности, основные направления и проблемы внедрения этих мероприятий на практике.

Для исследования была использована укрупненная группировка КСО теорий, включающая инструментальные, политические, интеграционные и этические теории. Рассмотрен ряд современных ключевых направлений исследования, в том числе взаимосвязь концепций КСО и стратегического управления.

На основании материалов исследований украинских ученых проанализированы основные направления, формы и проблемы реализации социально ответственных практик в Украине.

Ключевые слова: корпоративная социальная ответственность (КСО); корпоративная репутація; социально ответственные практики; стейкхолдеры; бизнес-среда.

\author{
Н. В. Орлова, \\ кандидат економічних наук, доцент, \\ доцент кафедри менеджменту та інновацій \\ Одеський національний університет імені I. І. Мечнікова \\ Французький бульвар, 24/26, 65058, м. Одеса, Україна \\ e-mail: lemorl@rambler.ru
}

\section{ТЕОРЕТИЧНІ ДОСЛІДЖЕННЯ І ПРОБЛЕМИ РЕАЛІЗАЦІЇ СОЦІАЛЬНОЇ ВІДПОВІДАЛЬНОСТІ БIЗНЕСУ}

Метою статті є аналіз концептуальних основ соціальної відповідальності бізнесу та проблем реалізації соціально відповідальних практик в Україні. У роботі представлений огляд еволюції поняття корпоративної соціальної відповідальності, основні напрямки та проблеми впровадження цих заходів на практиці.

Для дослідження було використане угруповання КСВ теорій, що включає інструментальні, політичні, інтеграційні та етичні теорії. Розглянуто ряд сучасних ключових напрямків дослідження, в тому числі взаємозв'язок концепцій КСВ і стратегічного управління.

На підставі матеріалів досліджень українських вчених проаналізовано основні напрямки, форми і проблеми реалізації соціально відповідальних практик в Україні. 
Ключові слова: корпоративна соціальна відповідальність (КСВ), корпоративна репутація, соціально відповідальні практики, стейкхолдери, бізнес-середовище.

\section{References}

1. Hrishnova, O. A., Mishchuk, H. Y. \& Oliynyk, O. O. (2014). Sotsial'na vidpovidal'nist' u trudovykh vidnosynakh: teoriya, praktyka, rehulyuvannya ryzykiv [Social responsibility in labor relations: theory, practice, risk management]. Rivne: NUVGP [in Ukrainian].

2. Bowen, H. R. (1953). Social Responsibilities of the Businessman. New York: Harper and Row.

3. Carroll, A. B. (1979). A Three-Dimensional Conceptual Model of Social Performance. The Academy of Management Review, Vol. 4, № 4, pp. 497-505.

4. Levitt, T. (1958). The Dangers of Social Responsibility. Harvard Business Review, Vol. 36, № 5, pp. 41-50.

5. Friedman, M. (1970). The Social Responsibility of Business is to Increase its Profits. The New York Times Magazine. URL: http://www.academia.edu/3267140/The social_responsibility_of_business_is_to_increase_its_profits

6. Kurenko, R. N. (2009). KSO: poisk kontseptualizatsii [CSR: the search for conceptualization]. KSO svoimi rukami-CSR do it yourself, 1, 28-29. Retrieved from: http://www.csrjournal.com. [in Russian].

7. Sethi, S. P. (1975). Dimesions of Corporate Social Perfomance: An Analytical Framework. California Management Review. Vol. 17, № 3, pp. 58-64.

8. Garriga, E. \& Mele, D. (2004) Corporate Social Responsibility Theories: Mapping the Territory. Journal of Business Ethics, No 53, p. 51. URL: http://www.environmentalmanager.org/wp-content/uploads/2008/04/csr-theories.pdf

9. Davis, K. (1967). Understanding The Social Responsibility Puzzle. Business Horizons, 10(4), pp. 45-51.

10. Davis, K. (1960). Can Business Afford to Ignore Corporate Social Responsibilities?, California Management Review, 2, pp. 70-76.

11. World Commission on Environment and Development: 1987, Our Common Future (Oxford University Press, Oxford). URL: https://sswm.info/sites/default/files/ reference_attachments/UN\%20WCED\%201987\%20Brundtland\%20Report.pdf

1. Boell, H. (2002). Foundation's Web Site on the World Summit for Sustainable Development, Johannesburg 2002. Retrieved from: www.worldsummit2002.org.

2. Rozvytok KSV v Ukrayini: 2010-2018 [Development of CSR in Ukraine]. (2017). Kyiv: Uston [in Ukrainian].

12. Directive 2014/95/EU of the European Parliament and of the Council of 22 October 2014 (amending Directive 2013/34/EU as regards disclosure of non-financial and diversity information by certain large undertakings and groups). URL: https://eurlex.europa.eu/legal-content/EN/TXT/PDF/?uri=CELEX:32014L0095\&from=EN 